\title{
Game of Thrones Sebagai Arsitektur Ekonomi Politik Global Versi Indonesia
}

\author{
Rico Dien Yudithadewi ${ }^{1}$, Bonifasius Santiko Parikesit ${ }^{2}$, Eka Wenats Wuryanta ${ }^{3}$ \\ yudithasuwarno@gmail.com, bonifasius.parikesit@gmail.com, ekawenatsw@gmail.com \\ 123 Graduate School of Communication, Universitas Paramadina Jakarta \\ DOI http://dx.doi.org/10.22219/sospol.v6i2.12015
}

\begin{abstract}
As part of the political communication channel, speech is an essential tool to convey messages, especially at the global political scope. In a speech at the IMFWorld Bank 2018 meeting, President Joko Widodo used the phrase 'winter is coming' from the story of the popular television series Game of Thrones as a presupposition of the global political economy situation. Based on President Jokowi's speech, this paper aims to understand the changes in the international political architecture caused by the spirit of economic liberalism from developed countries. The study applied the discourse analysis approach of Norman Fairclough's version. Referring to Fairclough, presuppositions are the key to understanding how reality is differentiated and presented. In examining the contents of the speech, the author will choose words/sentences that lexically relate to Game of Thrones or the context of de-globalization through the phenomenon of protectionism and trade war. The speech represents an attempt to protest from developing countries to the superpower countries. President Jokowi reminded superpower countries that the protectionism and trade wars will only lead to deglobalization. Instead of competing for power domination, Indonesia is calling for the idea of an equilibrium hegemony in the political economy to all member-states.
\end{abstract}

\begin{abstract}
Abstrak
Sebagai bagian dari saluran komunikasi politik, pidato merupakan ajang penting untuk menyampaikan pesan, terutama pada tataran politik global. Dalam pidatonya di IMF 2018 - Bank Dunia yang menayangkan serial televisi populer Game of Thrones untuk mencerminkan ekonomi politik global. Berdasarkan pidato Presiden Jokowi, makalah ini bertujuan untuk memahami perubahan arsitektur internasional sebagai implikasi dari perilaku negara maju yang meninggalkan semangat liberalisme ekonomi. Makalah ini menerapkan pendekatan analisis wacana versi Norman Fairclough. Merujuk pada Fairclough, praanggapan adalah kunci untuk memahami bagaimana realitas dibedakan dan disajikan. Dalam menelaah isi pidatonya, penulis akan memilih kata / kalimat yang secara leksikal berhubungan dengan Game of Thrones atau konteks de-globalisasi melalui fenomena proteksionisme dan perang dagang. Pidato tersebut merupakan upaya negara berkembang untuk melancarkan protes ke negara hegemon tersebut. Presiden Jokowi mengingatkan negara adidaya bahwa proteksionisme dan perang dagang hanya akan mengarah pada de-globalisasi. Alih-alih memperebutkan dominasi kekuasaan, Indonesia justru menyerukan gagasan hegemoni ekuilibrium dalam ekonomi politik kepada semua negara anggota.
\end{abstract}

\author{
Keywords: \\ Discourse Analysis, \\ De-globalization, Protectionism, \\ Speeches, Trade Wars
}

\section{Article History:}

Received May 2, 2020

Revised June 16, 2020

Accepted September 7 , 2020

Published October 17, 2020

\section{Corresponding Author}

Dien Yudithadewi.

Universitas Paramadina

Program Studi Ilmu

Komunikasi

Jl. Jend. Gatot Subroto kav. 97, Mampang, Jakart

Selatan. 12790

\section{Pendahuluan}

Pidato seorang pemimpin politik dapat diperlakukan sebagai kategori wacana bisnis, jika isinya terkait dengan bisnis dan ekonomi (Imani \& Habil, 2015). Di forum Sidang Tahunan Dana Moneter Internasional - Bank Dunia di Bali tanggal 12 Oktober 2018, Presiden Joko Widodo menganalogikan kondisi ekonomi dunia dengan istilah "winter is coming" yang diambil dari serial televisi terkenal, Game of Thrones/GoT, adaptasi dari buku berjudul A Song of Ice and Fire karangan 
George R.R Martin (Putera, 2018). Serial TV ini berkisah mengenai pertentangan politik di tujuh kerajaan di benua fantasi bernama Westeros, yang telah mengudara sejak tahun 2011 dan berhasil membawa pulang 12 penghargaan pada ajang Emmy Awards 2016. GoT memiliki tautan nilai yang mendidik serta mampu menampilkan karakter manusia secara utuh dalam hal perebutan kekuasaan (Poscheschnik, 2018)

Dalam pidatonya, dengan lugas Presiden Joko Widodo menuturkan sengitnya pertarungan antar kubu (houses) dan wangsa (families) pada film tersebut, tanpa mereka menyadari bahwa ada bahaya lain yang mengancam, yakni evil winter yang akan melingkupi bumi dengan es dan kehancuran. Jika pertarungan diteruskan, yang kalah hancur, demikian juga yang menang (Putera, 2018).

Pidato yang disampaikan para pemimpin negara dapat menjadi saluran komunikasi politik untuk menyampaikan pesan tentang dukungan moral (Fay \& Kuypers, 2012), perebutan kekuasaan, kritik terhadap ketimpangan ekonomi, serta mengkonstruksi kekuasaan dan ideologi (Hidayat, 2014; Imani \& Habil, 2015; Shurfa \& Shukry, 2013). Sementara "protes" pemimpin negara yang disampaikan melalui pidato kepada pihak yang berkuasa dan lembaga internasional, tampak pada pidato Perdana Menteri Jepang Shinzo Abe dalam penelitian Hidayat (Hidayat, 2014) dan pidato Mahathir Muhamad (Shurfa \& Shukry, 2013).

Penelitian ini menggunakan teori wacana versi Norman Fairclough yang berpendapat bahwa teks mempunyai konteks (Putra \& Triyono, 2018). Hamad menyatakan analisis wacana merupakan sebuah metode sekaligus teori, karena memang pada mulanya metode analisis wacana adalah sebuah teori (Hamad, 2007). Walaupun pengandaian hanyalah salah satu aspek wacana politik, memahaminya adalah langkah awal memahami bahasa politik secara keseluruhan (Hidayat, 2014). Merujuk pada Fairclough, pengandaian menjadi kunci untuk memahami bagaimana realitas dibedakan dan ditampilkan. Pengandaian bukan sebatas persoalan keindahan ragam lisan, melainkan juga cara memandang realitas.

\section{De-Globalisasi}

Presiden Joko Widodo dalam pidatonya di pertemuan IMF - Bank Dunia tahun 2018, menggunakan ungkapan "winter is coming" untuk mengandaikan situasi ekonomi politik global yang memburuk akibat perseteruan negara-negara terkuat, seperti Amerika Serikat dan Tiongkok. Pada saat pidato dibacakan, Presiden Amerika Serikat Donald Trump telah mengeluarkan kebijakan yang cukup kontroversial berkaitan dengan hubungan dagang dengan beberapa negara mitra.

Secara tersirat, pidato Presiden Joko Widodo menyuarakan kekhawatiran dan protes atas globalisasi yang "terancam" (de-globalisasi). Padahal globalisasi digambarkan para ekonom sebagai hubungan saling ketergantungan yang tumbuh dari perdagangan lintas batas barang dan jasa, teknologi, aliran investasi, orang, serta informasi (The Peterson Institute for International Economics, 2019). Tujuannya untuk mencapai kesejahteraan global.

Istilah Globalisasi telah muncul sejak tahun 1960-an dan telah digunakan dalam banyak literatur serta kajian akademik (Steger, 2003). Selama hampir tiga perempat abad, Amerika Serikat (AS) telah memimpin dunia ke dalam sistem perdagangan berbasis aturan yang berlaku global (Stiglitz, 2018a), puncaknya pada tahun 1995, World Trade Organization didirikan.

Dalam artikelnya yang berjudul The Overselling of Globalization, Stiglitz menyatakan efek globalisasi itu nyata dan gambling (Stiglitz, 2017). Globalisasi dipercaya dapat membawa 
keuntungan perdagangan dan meningkatkan kemakmuran suatu negara. Stiglitz pun menyatakan apabila dikelola dengan baik globalisasi akan membawa hasil positif bagi masyarakat (Stiglitz, 2002). Dampaknya berupa (1) produk impor yang lebih murah; (2) "paksaan" bagi pasar untuk mendorong efisiensi dan produktivitas, (3) peningkatan lapangan kerja seiring masuknya investasi asing yang sarat dengan alih teknologi serta (4) masuknya hasil output barang, maupun jasa dalam rantai pasok global menjadi ciri utamanya. Bahkan secara lebih mendalam, globalisasi telah memungkinkan perusahaan untuk mengambil keuntungan bukan semata dari perbedaan biaya tenaga kerja akibat sistem pengupahan yang berbeda di tiap negara, tetapi juga dari biaya yang timbul akibat perbedaan standar peraturan perpajakan (Stiglitz, 2015).

Dalam tingkat globalisasi yang optimal, arus produk dan faktor-faktor produksi (seperti tenaga kerja dan modal) lintas negara atau regional akan selancar lintas kota di dalam suatu negara atau desa di dalam suatu kecamatan. Orang tidak lagi memedulikan apakah produk pasta gigi merek Pepsodent berasal dari suatu perusahaan multinasional asal Belanda dan Inggris bernama Unilever meski proses pembuatannya bukan di Belanda maupun di Inggris, namun di salah satu kota di Provinsi Jawa Barat. Dalam alur yang sama bahkan banyak barang yang tidak lagi mencantumkan bendera dari negara asal dan/atau tidak mencantumkan merek dagang yang dimilikinya agar bisa kembali dijual sesuai kebutuhan konsumen tingkat pertama. Hal ini dapat kita lihat dalam distribusi batik cetak mesin asal Tiongkok yang dijual di pasar Jawa Tengah.

Semakin menipisnya batas-batas geografi dari kegiatan ekonomi secara nasional maupun regional berjalan beriringan dengan semakin hilangnya kedaulatan suatu pemerintahan negara yang menurut Halwani disebabkan oleh komunikasi dan transportasi yang semakin canggih dan murah, devisa yang semakin bebas, ekonomi negara yang semakin terbuka, penggunaan secara penuh keunggulan komparatif dan keunggulan kompetitif tiap-tiap negara dan semakin pesatnya perkembangan perusahaan multinasional di hampir seantero dunia (Halwani, 2002).

Namun, memasuki tahun 2016 justru Amerika Serikat sebagai negara dengan kekuatan ekonomi terbesar mulai berpaling dari ide tentang globalisasi yang selama ini didengungkannya. Negara tersebut cenderung memposisikan diri sebagai negara yang sebatas memikirkan kepentingan sendiri, dan berproses untuk melakukan deglobalisasi. Padahal deglobalisasi justru dapat menyebakan ekonomi menjadi kian lemah (Stiglitz, 2017). Kekuatan militer dan keuangan yang selama ini dijadikan instrumen untuk mendominasi tatanan global seolah memudar, Amerika Serikat pun abai terhadap gejolak dunia. Hal ini tidak terlepas dari arah kebijakan politik Amerika Serikat yang berubah, seiring bergesernya tampuk kekuasaan ke tangan Presiden Donald J. Trump.

Presiden Joko Widodo menyampaikan kekhawatiran tersebut. Indonesia mengawali pidatonya dengan menyinggung Krisis Finansial Global 2008, dan mengapresiasi langkah yang telah dilakukan banyak pihak dalam menyelamatkan ekonomi global.

"Setelah 10 tahun berlalu .... Kita tetap harus waspada terhadap meningkatnya resiko ... dan kesiapsiagaan kita dalam mengalami ketidak-pastian global. Seperti yang disampaikan Nyonya Lagarde... terdapat banyak masalah yang membayangi perekonomian dunia... Amerika Serikat menikmati pertumbuhan yang pesat... namun di banyak negara terdapat pertumbuhan yang lemah atau tidak stabil ...Perang Dagang semakin marak... dan inovasi teknologi mengakibatkan banyak industri terguncang. Negara-negara yang tengah tumbuh .... juga sedang mengalami tekanan pasar yang besar..Dengan banyaknya masalah perekonomian dunia, sudah cukup bagi kita untuk mengatakan bahwa: Winter is Coming." 
Kalimat ini disampaikan untuk menyamakan kondisi global yang terjadi sepanjang 2018 layaknya kisah dalam serial GoT dimana setiap House memiliki slogan dan Winter is Coming adalah slogan House Stark of Winterfell yang merupakan kepala wilayah utara. Selain berposisi sebagai sebuah slogan, "Winter is Coming" juga merupakan peringatan akan ancaman bahwa musim salju akan dating (Poscheschnik, 2018). Sebagai House yang terletak di wilayah utara, House Stark of Winterfell menjadi salah satu pihak yang pertama tahu bahwa musim salju akan datang, dan di Go'T musim salju bukan merupakan hal yang membahagiakan.

AS dalam kuasa pemerintah Trump telah banyak memainkan peran yang membingungkan serta membuat frustasi banyak pihak. Bahkan seolah bermain dengan kondisi yang populer disebut trembling hand equilibrium merujuk pada salah satu kasus teori permainan (game theory) yakni suatu keseimbangan yang dipandang optimal, gagal tercapai karena pihak yang terlibat terlalu berlebihan dalam berstrategi, dan terlalu percaya diri (Kuncoro, 2019).

Dampaknya, dunia telah berjalan tertatih dan tidak seimbang. AS sebagai pelaku utama dalam sistem global telah menjauh dari semangat multilateralisme. Periode 2018 menjadi catatan khusus tentang bagaimana AS memancing perseteruan di antara negara adidaya yang pada akhirnya hanya akan menyebabkan malapetaka yang membawa kegetiran bagi seluruh isi dunia. Alih-alih bersaing memperebutkan dominasi kuasa, Indonesia menyerukan gagasan ekuilibrium hegemoni dalam ekonomi politik, kepada para pemangku kepentingan, melalui pidato tersebut.

Dengan demikian, penelitian ini berfokus pada pesan tersirat Presiden Joko Widodo dalam Pidato "Winter is Coming". Hasil penelitian diharapkan bisa memberikan wawasan yang lebih luas mengenai isu de-globalisasi, yang menurut Stiglitz terjadi akibat proteksionisme dan perang dagang (Stiglitz, 2017). Juga dapat menjadi salah satu referensi dalam memberikan kesadaran kepada masyarakat bahwa dalam setiap pernyataan politik, termasuk pidato, terkandung gagasan, serta tujuan tertentu. Oleh karena itu, hendaknya tiap argumen dicermati dengan membaca pesan yang tersirat, disamping yang tersurat.

\section{Metode}

Tulisan ini menggunakan metode penelitian kualitatif deskriptif dengan pendekatan analisis wacana versi Norman Fairclough. Untuk memahami realitas di balik teks dibutuhkan penelusuran konteks dan aspek sosial budaya yang mempengaruhi penulisan teks tersebut (Hamad, 2007; Wang, 2016). Pendekatan ini dipilih karena dapat menjadi alat untuk untuk mendalami isi pidato. Tidak seperti analisis isi yang bertumpu pada data empirik berupa tulisan atau simbol, analisis wacana mampu merangkum hal-hal yang tidak tertulis dan tidak konkret.

Implikasinya, bahasa tidak lagi dipandang semata sebagai alat untuk memahami, tetapi juga untuk mengungkapkan aktor utama atau faktor sentral dalam kegiatan wacana serta hubungan-hubungan sosialnya (Habiburrahim, Rahmiati, Muluk, Akmal, \& Aziz, 2020; Hamad, 2007). Dalam perspektif non-positivistik, bahasa juga dipahami sebagai representasi yang berperan dalam membentuk subjek, tema, maupun strategi-strategi di dalamnya (Ghafur, 2016). Murray Edleman menggambarkan diskursus politik sebagai simbol manipulasi realita demi mencapai tujuan politik (Schiffrin, Tannen, \& Hamilton, 2001). 
John Wilson dalam Schiffrin menyatakan bahwa kata maupun kalimat yang sama dapat diintepretasikan berbeda, terutama dalam konteks politik (Schiffrin et al., 2001). Untuk itu, penggunaan analisis wacana terhadap pembicaraan atau teks dalam konteks, dapat membantu peneliti komunikasi untuk mempelajari bagaimana individu: (1) menampilkan dirinya (persona), (2) mengatur hubungan, (3) mengambil tanggung jawab dan menyalahkan, (4) membuat organisasi, (5) membangun budaya, (6) mempersuasi orang lain, (7) mendorong interaksi sosial, dan sebagainya.

Dalam menelaah isi pidato "winter is coming", penulis akan memilih kata/kalimat yang secara leksikal berhubungan dengan Game of Thrones atau konteks de-globalisasi melalui fenomena proteksionisme, dan perang dagang.

\section{Hasil dan Pembahasan}

\section{Proteksionisme Perdagangan Amerika}

Melalui banyak keputusan kontroversialnya, Trump mengarahkan politik luar negeri AS untuk memprioritaskan kesejahteraan ekonomi. Terdapat banyak argumen yang dibangun Trump untuk melegitimasi kondisi tersebut dan salah satunya ialah, globalisasi dianggap tidak adil bagi AS (Carvalho, Azevedo, \& Massuquetti, 2019). Ini adalah klaim yang “menggelikan” karena AS selalu mendominasi negosiasi perdagangan, juga mendapatkan bagian terbesar dari negosiasi yang dilancarkannya. Hanya Uni Eropa yang memiliki posisi tawar yang setara (Stiglitz, 2018b).

Setelah berakhirnya Perang Dunia Kedua, AS berhasil mencengkeram perekonomian dengan memasok setengah dari Produk Global Bruto di tahun 1950 dan menempatkan dirinya sebagai produsen manufaktur terbesar di dunia dengan cakupan porsi mencapai $60 \%$. Namun demikian, menurut rilis data Forbes, meski institusi AS masih memiliki dominasi yang cukup besar, porsi persentasenya terus merosot. Memasuki tahun 1999, industri manufaktur melorot hingga menyisakan angka 25\% dan pada tahun 2018 sumbangan ekonomi AS terhadap Produk Global Bruto sebatas 21\%.

Kecenderungan proteksionisme yang diambil AS juga dilakukan beberapa negara selama 3 dekade ke belakang akibat munculnya ketimpangan ekonomi sosial. Alih-alih memperbaiki kondisi yang ada, Trump memilih jalan yang keras untuk memperbaiki kondisi ekonomi negerinya (Bimantara, 2019). Ia secara agresif melancarkan serangkaian kebijakan perlindungan pasar dalam negeri berbentuk pengenaan tarif, baik kepada para sekutu tradisional, maupun mitra dagang aktif. Tindak tersebut dilakukan melalui aksi: (1) Perlindungan terhadap produsen mesin cuci AS dan Produk Tenaga Surya dan (2) Penyelidikan atas paksaan transfer teknologi, praktik perizinan yang tidak adil dan pencurian hak kekayaan intelektual

Berdasar Section 201, pada tahun 2018 Presiden Trump mengeluarkan serangkaian perlindungan perdagangan untuk melindungi produsen mesin cuci AS dan produk energi surya dari banjir impor luar negeri. Ini adalah penggunaan pertama Section 201 dalam 16 tahun terakhir. Melalui instrumen kebijakan ini, Presiden Trump ingin memastikan bahwa perusahaan asing seperti Samsung dan LG memiliki komitmen dan tanggung jawab dalam membangun infrastruktur produksi mereka di tanah AS.

Sementara dalam konteks HKI, berdasarkan Section 301, pemerintahan Trump melakukan penyelidikan atas dugaan praktik anti-dumping di 82 kasus atau meningkat 58\% dibanding penyelidikan yang dilakukan Pemerintahan Obama. Selain itu pemerintahan Trump 
juga memulai beberapa penyelidikan berdasar Section 232 mengenai potensi risiko keamanan nasional berkaitan dengan praktik impor baja dan aluminium. Hasil dari penyelidikan ini menemukan bahwa impor yang dilakukan telah mengancam keamanan nasional. Khusus untuk poin ini, Trump menekankan pada praktik bisnis yang tengah berjalan tidak seimbang antara AS dan Tiongkok.

Seperti perang fisik, perang dagang dua raksasa ekonomi dunia yaitu AS dan Tiongkok melibatkan aktivitas saling serang dengan senjata pajak, kuota dan tarif. Perselisihan antar dua negara tersebut secara sederhana terjadi akibat defisit neraca perdagangan yang mencapai 419 miliar dollar AS, tuduhan pencurian teknologi dan hak paten serta tuduhan intervensi pemerintah pada industri teknologi seperti yang diduga terjadi pada Huawei. Bagi banyak pengamat ekonomi, AS mencoba menekan sektor unggulan Tiongkok untuk menghambat realisasi visi Made in China 2025.

Proteksionisme dan Perang Dagang telah menjadi tema-tema pembahasan media arus utama dalam lima tahun ke belakang akibat praktik globalisasi yang dianggap tidak memberikan banyak manfaat utamanya bagi negara maju seperti Amerika Serikat. Padahal, globalisasi dengan ciri liberalisme telah mengajarkan manusia mengenai prinsip keunggulan komparatif dan manfaat perdagangan. Kita berdagang bukan untuk memberikan manfaat kepada negara lain, melainkan untuk meningkatkan peluang ekonomi warga negara kita sendiri (Rodrik, 2017).

Dalam artikelnya yang berjudul Trump dan Globalisasi Baru, Pangestu menyebutkan bahwa periode ketiga dari globalisasi muncul dengan perdagangan yang semakin didominasi arus pertukaran ide, pengetahuan dan jasa (Pangestu, 2017). Pada kondisi ini, perdagangan bukan lagi mengenai barang, melainkan berbentuk pekerjaan dan bagian dari proses produksi yang dilakukan offshore atau dikerjakan di negara lain dengan pertimbangan biaya.

Alokasi pembebanan biaya yang tinggi untuk suatu proses produksi menjadi alasan banyak sektor industri berpaling meninggalkan Amerika Serikat. Hal inilah yang kemudian dielaborasi Trump untuk melakukan tindak proteksionisme dan perang dagang yang kemudian membawa dunia dalam deglobalisasi. Memang benar apabila dalam kondisi tertentu perdagangan dikatakan tidak memberikan manfaat bagi masyarakat secara luas. Namun tindak saling membalas proteksionisme dan perang dagang hanya akan membawa kerugian bagi para pihak.

Secara lugas, Presiden Joko Widodo dalam pidato tersebut menyampaikan kondisi ekonomi global memasuki tahun 2018, berada dalam bayang ketidakpastian akibat ancaman proteksionisme dan perang dagang. Ia mengemas dan menghubungkan rangkaian pesan pidato tersebut dengan serial Game of Thrones. Game of Thrones berkisah mengenai pertentangan politik di tujuh kerajaan di benua fantasi bernama Westeros. Dalam alur cerita yang berjalan, GoT menampilkan sebuah drama perebutan kekuasaan yang dituturkan oleh Presiden Joko Widodo, "Namun akbir-akbir ini, bubungan antar negara-negara ekonomi maju... semakin lama semakin terlihat seperti Game of Thrones..." (Kementerian Sekretariat Negara RI, 2018).

Kalimat ini disampaikan untuk mengelaborasi laku dan lakon yang tengah dijalankan raksasa ekonomi dunia (baca: AS) yang pada tahun 2018 banyak melancarkan manuver untuk mengejar hegemoni dengan meninggalkan para sekutu tradisional dan mitra strategis. Dengan alasan gangguan keamanan nasional, Pemerintahan Trump secara sepihak menerapkan tarif produk tertentu dan kadang penyebabnya pun sederhana. Di Prancis misalnya, ancaman perang dagang mencuat setelah negeri itu menerapkan pajak atas layanan digital yang dinilai AS 
mendiskriminasi dan memberatkan perusahaan teknologi asal AS seperti Google, Apple, Facebook dan Amazon. Atas aksi yang dilakukan Prancis, AS mengancam mengenakan tarif impor hingga 100\% terhadap produk negara tersebut berupa minuman anggur, soda, keju dan yoghurt yang ditaksir memiliki nilai 2,4 miliar dollar AS. Selanjutnya Presiden Trump berencana untuk mengenakan tarif tambahan atas produk baja yang diekspor Brazil, setelah Presiden Bolsonaro - yang dijuluki Trump of the Tropics - menjalin hubungan dagang intens dengan Tiongkok.

Hal ini sangat jelas meresahkan Indonesia dan banyak negara berkembang lainnya, menyaksikan perebutan kekuasaan ekonomi dunia yang tengah terjadi. AS seolah lupa bahwa krisis 2008 yang bersumber dari subprime mortage atau kredit perumahan berasal dari negaranya. Dunia kala itu berhasil keluar dari kondisi yang terjadi karena kolaborasi sempurna antar pemerintah AS, Inggris, Jerman, dan IMF dalam memompa ekonomi AS dengan pemberian dana talangan agar potensi rambatan krisis dapat cepat ditangani.

"Dalam serial Game of Thrones, sejumlah Great Houses, Great Families... bertarung hebat antara satu sama lain, untuk mengambil alih kendali... the Iron Throne. Mother of Dragons menggambarkan siklus kehidupan. Perebutan kekuasaan antar para Great Houses itu bagaikan sebuah roda besar yang berputar. Seiring perputaran roda..., satu Great House tengah Berjaya, sementara House yang lain menghadapi kesulitan... dan setelahnya,... House yang lain berjaya, dengan menjatuhkan House yang lain.”

Berdasarkan kalimat tersebut, negara-negara adidaya digambarkan sebagai Great Houses yang bersaing untuk menguasai dominasi ekonomi dunia (the Iron Throne). Perebutan kekuasaan direfleksikan dengan roda besar yang berputar, dimana ada pihak yang di atas (berjaya) dan yang lain tergerus di bawah (menjatuhkan House yang lain). Paparan ini menunjukkan betapa mengkhawatirkannya kondisi ekonomi global di tahun 2018, masa dimana Amerika Serikat sebagai negara adikuasa banyak menerapkan kebijakan ekonomi yang kurang menguntungkan bagi negara lain. Secara sepihak, AS melakukan banyak amandemen perjanjian perdagangan bebas dengan berbagai negara yang dianggap tidak menguntungkannya.

\section{Perang Dagang}

Perang dagang yang terjadi dalam kurun lima tahun belakangan bukanlah sesuatu yang benar-benar baru. Pertama kali perang dagang terjadi pada tahun 1930 saat AS berseteru dengan Spanyol, Kanada, Swiss dan Italia akibat aksi sepihak AS yang menjatuhkan tarif ke lebih dari 20.000 produk agrikultur dan industri melalui Smoot-Hawley Tarrif Act. Pemerintah negara yang berseteru dengan AS pun segera menerbitkan kebijakan serupa sebagai aksi balasan. Insiden ini pada akhirnya memicu ekonomi global masuk dalam resesi yang dikenal dengan sebutan Great Depression.

Memasuki dekade 1980-an ketika bangkitnya Jepang sesudah serangan atom yang meluluhlantakan Hiroshima dan Nagasaki pada Perang Dunia Kedua, gerak industri di Jepang mengalami pertumbuhan signifikan dan mendominasi pasar global. Serupa dengan kasus yang terjadi tahun 1930, pasar AS pada periode tersebut dibanjiri produk otomotif, semikonduktor dan elektronik asal Jepang yang menawarkan harga "murah" akibat lompatan inovasi teknologi. Selepas serangkaian aksi, Jepang pada akhirnya bersepakat untuk mengurangi ekspor otomotifnya secara bertahap melalui mekanisme Voluntary Export Restraint (Baldwin \& Krueger, 1984). 
Dalam rentang satu abad terakhir, AS sendiri setidaknya telah mengalami delapan perang dagang yang melibatkan Swiss, Jerman, Jepang, Prancis, Meksiko, Kanada dan Tiongkok. Berdasarkan informasi tentang tarif perdagangan AS sepanjang 2018, terlihat bahwa kebijakan diberlakukan terhadap Vietnam, Thailand, Korea Selatan untuk komoditas mesin cuci sebesar 16-20\%. Kebijakan lainnya meliputi komoditas baja (25\%), dan aluminium (10\%) untuk Uni Eropa, Kanada, India, dan Meksiko. Adapun terhadap Tiongkok diberlakukan untuk impor indutri menengah dan modal (Sakti, 2019). Dari aksi yang dilakukan oleh AS tersebut, beberapa negara menerapkan tarif balasan serupa untuk produk AS. Tiongkok bahkan secara langsung menembak sektor pertanian AS yang merupakan basis utama pemilih Republikan dengan rentang besaran $15-25 \%$. Kompetisi hegemoni pada skala ekonomi global tentu menyangkut persaingan dagang antar negara. Memasuki tahun 2016, gelombang globalisasi seolah menemukan titik balik dan konsep kolaborasi mencari pola keseimbangan baru.

Presiden Amerika Serikat ke-45 yang baru dilantik, Donald Trump, menyoroti lemahnya ekonomi negara tersebut dalam berproduksi. Bagi Trump, perekonomian AS hari ini lebih banyak ditopang konsumsi sehingga dianggap tidak mampu mendorong pertumbuhan ekonomi yang signifikan (Carvalho et al., 2019). Melalui kampanye Make America Great Again, ia menerapkan agenda kebijakan yang berorientasi pada keuntungan AS semata. Poin ini juga merupakan gambaran dari bagian isi pidato Presiden Joko Widodo sebagai berikut:

"Setelah 10 tahun berlalu .... Kita tetap harus waspada terhadap meningkatnya resiko ... dan kesiapsiagaan kita dalam mengalami ketidak-pastian global. Seperti yang disampaikan Nyonya Lagarde... terdapat banyak masalah yang membayangi perekonomian dunia... Amerika Serikat menikmati pertumbuhan yang pesat... namun di banyak negara terdapat pertumbuhan yang lemah atau tidak stabil ...Perang Dagang semakin marak... dan inovasi teknologi mengakibatkan banyak industri terguncang. Negara-negara yang tengah tumbuh .... juga sedang mengalami tekanan pasar yang besar.. Dengan banyaknya masalah perekonomian dunia, sudah cukup bagi kita untuk mengatakan bahwa: Winter is Coming."

Selanjutnya, persaingan dagang dan kondisi yang menyertainya tercermin di bagian lain pidato:

"Dalam serial Game of Thrones, sejumlah Great Houses, Great Families... bertarung hebat antara satu sama lain, untuk mengambil alih kendali... the Iron Throne. Mother of Dragons menggambarkan siklus kehidupan. Perebutan kekuasaan antar para Great Houses itu bagaikan sebuah roda besar yang berputar. Seiring perputaran roda..., satu Great House tengah Berjaya, sementara House yang lain menghadapi kesulitan... dan setelahnya,... House yang lain Berjaya, dengan menjatuhkan House yang lain."

Kalimat ini disampaikan untuk mengelaborasi agenda kebijakan AS yang berjalan semakin eksklusif dalam membangun relasi dagang internasional. Presiden Trump "menabuh genderang perang" persaingan dagang pada titik baru dengan rangkaian kebijakan ekonomi yang memberikan keuntungan dan kemakmuran semata bagi banyak rakyat AS, serta mendorong reformasi Organisasi Perdagangan Dunia (World Trade Organization/WTO) untuk mempromosikan aturan pasar yang lebih efisien, luas dan menawarkan distribusi kekayaan yang lebih adil (White House, 2018). Guna mendukung kelima pilar tersebut, AS secara agresif menyerang hubungan multilateral yang telah dibangun. Sikap agresif ini bahkan ditunjukkan kepada Kanada dan Meksiko sebagai tetangga terdekat di Amerika Utara melalui kebijakan perang tarif (BBC, 2020).

Selain memusuhi banyak negara, Trump sebagai representasi pemerintah AS yang tengah berkuasa, tanpa segan juga mengancam raksasa teknologi, Tiongkok. Huawei yang akses 
pasarnya untuk Teknologi 5G dihambat di AS, dan 70 afiliasinya juga dimasukkan dalam daftar hitam perdagangan. Hal ini berlanjut dengan perintah kepada Google dan para pemasok untuk menghentikan kerja sama bisnis dengan Huawei. Trump bahkan secara khusus menandatangani perintah ekslusif yang melarang perusahaan AS menggunakan peralatan telekomunikasi yang dibuat oleh perusahaan yang dianggap menimbulkan risiko keamanan dalam negeri. AS bahkan melobi banyak negara sekutu untuk tidak menggunakan infrastruktur teknologi Huawei di jaringan 5G (Sebenius \& Drozdiak, 2019).

Di samping rantai kebijakan yang dikeluarkan Trump, perkembangan dunia yang dipicu inovasi teknologi juga tidak kalah memanaskan suhu ekonomi global. Posisi teknologi di satu sisi diakui berhasil membuat hidup manusia menjadi produktif dan efisien, meski di satu sisi juga memangkas banyak pekerjaan. Laporan yang dirilis McKinsey Global Institute tahun 2017 dengan judul Jobs Lost, Job Gained: What the future of work will mean for jobs, skill and wages memprediksi akan terdapat 75 - 375 juta pekerjaan yang bakal tergantikan oleh mesin atau robot pada tahun 2030 (Manyika \& Dkk., 2017). Dalam konteks Indonesia misalnya, gelombang teknologi telah menggusur banyak media cetak, taksi konvensional dan perbankan yang masih menjalankan praktik lama dengan akses konsumen terbatas (Putri, 2020). Berangkat dari perang dagang dan inovasi teknologi inilah yang kemudian ditengarai memicu kontraksi ekonomi global dan melahirkan spillover effect terhadap ekonomi negara-negara di dunia (Ajami, 2020). Setidaknya terdapat sekitar 165 miliar dolar AS hilang dalam perdagangan global atau berpindah untuk mengindari pengenaan tarif (Amiti, Redding, \& Weinstein, 2019).

\section{Kesimpulan}

Momentum panggung ekonomi politik kelas dunia, seperti pertemuan IMF - Bank Dunia dapat menjadi ajang untuk menyampaikan pidato politik yang mengkritisi kondisi global. Saat pertemuan tersebut digelar di Bali pada tahun 2018, Presiden Joko Widodo melalui kisah Game of Thrones, khususnya ungkapan "winter is coming", mengingatkan potensi de-globalisasi akibat proteksionisme dan perang dagang.

Peran AS yang selama ini dipandang sebagai salah satu negara yang mendorong globalisasi, di era pemerintahan Trump menjauh dari gagasannya sendiri. Padahal globalisasi dengan ciri liberalisme telah mengajarkan manusia mengenai prinsip keunggulan komparatif dan manfaat perdagangan.

Walau dikemas dengan gaya kontemporer yang berkesan ringan, sesungguhnya pidato Presiden joko Widodo merupakan sebuah upaya pihak yang lemah (negara berkembang) untuk melontarkan "protes" kepada negara-negara "penguasa" ekonomi global. Melalui pidato tersebut, Presiden Joko Widodo menyerukan gagasan ekuilibrium hegemoni dalam ekonomi politik, kepada para pemangku kepentingan.

\section{Referensi}

Ajami, R. A. (2020). US-China Trade War: The Spillover Effect. Journal of Asia-Pacific Business, 21(1), $1-3$. https://doi.org/https://www.tandfonline.com/doi/pdf/10.1080/10599231.2020.1708 227? needAccess $=$ true

Amiti, M., Redding, S. J., \& Weinstein, D. (2019). The Impact of the 2018 trade war on US prices and welfare. Center for Economic Policy Research. Journal of Economic Perspectives, 
$33(4)$,

187-210.

Retrieved

from

https://www.aeaweb.org/articles?id=10.1257/jep.33.4.187

Baldwin, R. E., \& Krueger, A. O. (1984). The Structure and Evolution of Recent U.S. Trade Policy. Chicago: University of Chicago Press. Retrieved from http://www.nber.org/books/bald84-1

BBC. (2020). A quick guide to the US-China trade war. Retrieved June 16, 2020, from https://www.bbc.com/news/business-45899310

Bimantara, A. (2019). Donald Trump's Protectionist Trade Policy from the Perspective of Economic Nationalism. Jurnal Hubungan Internasional, 7(2), 189-204. https://doi.org/https://doi.org/10.18196/hi.72132

Carvalho, M., Azevedo, A., \& Massuquetti, A. (2019). Emerging Countries and the Effects of the Trade War between US and China. Economies, 45(7). https://doi.org/10.3390/economies7020045

Fay, I., \& Kuypers, J. A. (2012). Transcending Mysticism and Building Identification Through Empowerment of the Rhetorical Agent: John F. Kennedy's Berlin Speeches on June 26, 1963. Southern Communication Journal, 77(3), 198-215. https://doi.org/https://doi.org/10.1080/1041794X.2011.637601

Ghafur, A. (2016). Critical Discourse Analysis Sebuah Model Analisis Sosial Kritis Dalam Teks Media. OKARA Journal of Languages and Literature, 10(2).

Habiburrahim, H., Rahmiati, Z., Muluk, S., Akmal, S., \& Aziz, Z. A. (2020). Language, identity, and ideology: Analysing discourse in Aceh sharia law implementation. Indonesian Journal of Applied Linguistics, 9, 599-607. https://doi.org/10.17509/ijal.v9i3.23210

Halwani, R. H. (2002). Ekonomi Internasional dan Globalisasi Ekonomi. Bandung: Ghalia Indonesia.

Hamad, I. (2007). Lebih Dekat dengan Analisis Wacana. Mediator, 8(2).

Hidayat, H. (2014). Pemanfaatan Fitur Metafora dalam Teks Pidato Politik Shinzo Abe Sebagai Perdana Menteri Jepang Ke-96: Analisis Wacana Kritis. Metalingua, 12(2).

Imani, A., \& Habil, H. (2015). Discourse Analysis of Dr. Mahathir's Business Speech. Global Advances in Business and Communication Conference \& Journal, 4(1). Retrieved from https:/ / commons.emich.edu/cgi/viewcontent.cgi?article $=1027 \&$ context=gabc

Kementerian Sekretariat Negara RI. (2018). Pidato "Game Of Thrones" Presiden Jokowi di Annual Meeting IMF - WBG 2018. Retrieved March 12, 2020, from https://www.youtube.com/watch?v=BQbzDeQk-Ws

Kuncoro, A. (2019). Menyikapi Perang Dagang AS-China. Kompas.Id. Retrieved from https://kompas.id/baca/utama/2019/05/21/menyikapi-perang-dagang-as-china/

Manyika, J., \& Dkk. (2017). Jobs Lost, Job Gained: What the future of work will mean for jobs, skill and wages.

Pangestu, M. E. (2017). Trump dan Globalisasi Baru. Harian Kompas.

Poscheschnik, G. (2018). Game of Thrones A psychoanalytic interpretation including some remarks on the psychosocial function of modern TV series. The International Journal of Psychoanalysis, 99(4), 1004-1016. https://doi.org/10.1080/00207578.2018.1425092

Putera, A. D. (2018). "Winter is Coming" dari Jokowi, Sinyal Sekaligus Sindiran. Kompas.Com. Retrieved from https://ekonomi.kompas.com/read/2018/10/17/180700226/-winteris-coming-dari-jokowi-sinyal-sekaligus-sindiran 
Putra, H. P., \& Triyono, S. (2018). Critical Discourse Analysis on Kompas.com News: Gerakan \#2019GantiPresiden. Leksema, 3(2).

Putri, A. S. (2020). Pengaruh Perkembangan Ilmu dan Teknologi Terhadap Perubahan Ruang. Kompas.Com. Retrieved from https://www.kompas.com/skola/read/2020/06/24/163000969/pengaruhperkembangan-ilmu-dan-teknologi-terhadap-perubahan-ruang?page $=$ all

Rodrik, D. (2017). Growth Without Industrialization? Harian Kompas.

Sakti, R. E. (2019). Jangan Sampai Indonesia Jadi Pelanduk yang Mati dalam Perang Dagang. Kompas.Id. Retrieved from https://kompas.id/baca/utama/2019/07/09/jalurdiplomasi-perang-dagang-as/

Schiffrin, D., Tannen, D., \& Hamilton, H. E. (2001). The Handbook of Discourse Analysis. Blackwell Publishers.

Sebenius, A., \& Drozdiak, N. (2019). Europe Edges Toward 5G Restrictions After Blast of U.S. Lobbying. Retrieved June 15, 2020, from https://www.bloomberg.com/news/articles/2019-12-09/europe-edges-toward-5grestrictions-after-blast-of-u-s-lobbying

Shurfa, A., \& Shukry, M. (2013). A Critical Discourse Analysis of Mahathir Mohamad's Speeches on the "War on Terror." Intellectual DIscourse, 21(2).

Steger, M. B. (2003). Globalization: A Very Short Introduction. Oxford: Oxford University Press.

Stiglitz, J. E. (2002). Globalization and Its Discontents. New York: W.W. Norton.

Stiglitz, J. E. (2015). Rewriting The Rules of the American Economy: An Agenda for Growth and Shared Prosperity. New York: Roosevelt Institute.

Stiglitz, J. E. (2017). The Overselling of Globalization. New York.

Stiglitz, J. E. (2018a). Globalization and Its Discontents Revisited Anti Globalization in The Era of Trump. WW Norton \& Company, Inc.

Stiglitz, J. E. (2018b). Trump and Globalization. Journal of Policy Modeling, 40, 515-528. Retrieved from https://www8.gsb.columbia.edu/faculty/jstiglitz/sites/jstiglitz/files/Trump and Globalization Final.pdf

The Peterson Institute for International Economics. (2019). What Is Globalization? And How Has the Global Economy Shaped the United States? Retrieved June 15, 2020, from https://www.piie.com/microsites/globalization/what-is-globalization

Wang, J. (2016). A New Political and Communication Agenda for Political Discourse Analysis: Critical Reflections on Critical Discourse Analysis and Political Discourse Analysis. International Journal of Communication, 10, 2766-2784. Retrieved from https://ijoc.org/index.php/ijoc/article/view/3847/1679

White House. (2018). President Donald J. Trump is Promoting Free, Fair, and Reciprocal Trade. Retrieved June 15, 2020, from https://www.whitehouse.gov/briefingsstatements/president-donald-j-trump-promoting-free-fair-reciprocal-trade/ 